\title{
Grażyna Rytter
}

Uniwersytet Łódzki (Łódź, Polska)

\section{NAZWY CZĘŚCI TWARZY W JĘZYKACH SLOWIAŃSKICH}

Jest to szkic etymologiczny, który przedstawia 19 wyrazów tematycznych powiązanych z psł. *tvarb. Są to *borda, *bry, *lice, *nadoči / *nadočbje, *nosb, *nozdra / *nozdrb, *obličbje, *oboči / *obočbje, *obry / *obrbve, *obustbje, *oko, *ręsa / *ręsbna, *usta, *vědja, *věja, *věka / *věko, pst. dial. *vrgal.

*borda

Nazwa ogólnosłowiańska, spokrewniona z łotewsk. bārda, stwniem. bart (współcz. niem. Bart), łac. barba, oparta na pie. **bhar-//**Bhor- 'coś ostrego, sterczącego, szczecina' (Boryś SE, s. 39). Nazwa ta w językach słowiańskich posiada dwa znaczenia: 1. 'dolna, wystająca część twarzy poniżej ust', 2. 'zarost na dolnej części twarzy poniżej ust, szczecina’. Dwuznaczność ta jest prawdopodobnie bardzo stara.

*bry (Gen. Sg. *brbve, Acc. sg. *brbvb) 'brew'

Większość form słowiańskich kontynuuje Acc. sg. *brbv- / *brbvb, rzeczownika z tematem - $\bar{u}$ - (z przejściem do deklinacji - $\breve{l-)}$; pie. **bhrū 'brew' (Boryś SE, s. 39; ESSJ, t. III, s. 63-64, por. stang. bru' 'brew' (ang. brow), litewsk. bruvis 'ts.' (Czernych IES, t. I, s. 112).

Ogsłow.: stczes. brvi' 'bri' (Geb SL, t. I, s. 102),

czes. brva (f.) 1. 'rzęsa' (u powieki), 2. zool. 'rzęski (u robaków)';

sła. brva 'brew'; 'rzęsy'; zwykle w pl. bry 1. 'rzęsy'; 'brwi'; 2. zool. 'włoski na ciele niektórych niższych organizmów zwierzęcych',

stpol. breẃ, brwi; w XVI w. także 'miejsce porastania brwi'; 'powieka; rzęsa',

pol. brew, Gen. sg. brwi; dial. także brwia;

${ }^{1}$ Artykuł ten czerpie inspirację z pracy Janusza Siatkowskiego, ograniczony jest jednakże do propozycji etymologicznych, ponieważ szczegóły opracował już Pan Profesor, por. Siatkowski 2010. 
scs. бръвь 'rzęsa'; 'brew';

błg. gwar. бръв (m.) 1. 'czułki owada'; 'rogi ślimaka',

błg. бръва 'powieka'; 'wąs';

ch. / s. (rzadkie, dawne) br̂w (f.) 'powieka';

strus., crus. бръвь, бровь (Srez M, t. I, s. 181);

ros. бровь 'włosy ułożone łukiem nad oczodołem', także 'łuk brwiowy nad oczodołem'; dial. бровь 'powieka'; rzęsa';

ukr. брова (f.) 'brew';

brus. брывво (n.) 'brew'; gwar. брывва́ (f.) 'ts.'

*lice (n.)

'twarz, oblicze'; 'zewnętrzna powierzchnia czegoś'; 'zewnętrzna forma, postać'

Starsza postać **likb / **liko zachowała się szczątkowo w pdsłow. i wschsłow.: forma psł. *lice przedstawia rezultat III palatalizacji $k \geq c$. Jest to rzeczownik utworzony zapewne od czasownika *ličiti 'formować, kształtować' ze znaczeniem pierwotnym 'dokładne wyobrażenie czegoś'2.

Ogsłow.: czes. lice 'twarz',

stczes. 'policzek, szczęka'; 'zewnętrzna, właściwa strona czegoś’;

głuż., dłuż. lico 'policzek';

stpol. lice 'oblicze, twarz'; 'policzek'; 'kształt, postać';

ros. лицио 'oblicze, twarz'; 'osoba'; 'zewnętrzna strona czegoś, np. tkaniny'; dial. 'policzek'; przestarz. лик 'twarz'; 'wygląd zewnętrzny';

strus. ликъ 'twarz';

maced. dial. лико 'oblicze, twarz'; 'ktoś odpowiedni; dobrana para';

słń. lìk 'postać, kształt'; 'wyobrażenie'.

W polszczyźnie od XIV wieku poświadczona jest nazwa policzek (m.) 'część twarzy'; 'uderzenie w twarz', utworzona od wyrażenia przyimkowego po licu 'po twarzy’ (Boryś op. cit., s. 460; Br SE, s. 298).

*nadoči / *nadočbje

Kompozitum zbudwane z *nad(b) i *oko (Du. *oči), przekształcone przez przyrostek *-bje (ESSJ, t. XXII, s. 11);

czes. nadoči (n.) 'brwi' (Jungmann, t. II, s. 554);

sła. nadočie = obočie;

dłuż. nadwoczy (Du. n.) 'powieka' (Muka, t. I, s. 968);

głuż. nadwoči ‘żółte pasemka nad oczami u psów’ (Pfuhl, s. 396).

Przedrostek *nad-występuje w znaczeniu 'nad czymś', np. nad brwiam, czołem, powiekami, oczami (ESSJ, t. XXX, s. 243).

\footnotetext{
${ }^{2}$ Etymologia wg Boryś SE, s. 39; Czernych IES, t. I, s. 112; ESSJ, t. III, s. 63-64.
} 
*nosъ (m.) 'nos'

Nazwa ogólnosłowiańska, spokrewniona z mającymi to samo znaczenie litewsk. nósis, stwniem. nasa (współcz. niem. Nase), łac. nāsum (nāsus) (nasus), awest. nāh- (m.) 'nos'; pie. **nos - 'nos'; por. *nozdra /*nozdrb ${ }^{3}$.

*nozdra / *nozdrb 'otwór w nosie, nozdrze'

Nazwa ma odpowiednik w litewsk. nasrai (pl.) 'paszcza'; pie. **nasrā, które prawdopodobnie było urzeczownikowioną formą rodzaju żeńskiego przymiotnika **nas-ro-, 'nosowy, należący do nosa', z przyrostkiem **-ro-(:pie. **nas- 'nos'). W językach słowiańskich nastąpił rozwój fonetyczny *nosr- > *nozr- > *nozdr-, tj. udźwięcznienie grupy spółgłoskowej i wstawne -d- (Boryś, op. cit., s. 367). Vas ES, t. III, s. 80-81 rekonstruuje *nozdrba $\left(:{ }^{*}\right.$ nosb $+*$ dero $)$, a jako mniej prawdopodobną traktuje etymologię **nos- + $* *-d^{h} r o-$.

Ogsłow.: czes. nozdra;

pol. nozdrze, zwykle w pl. nozdrza 'otwory zewnętrzne nosa', stpol. nozdrze / nozdrza 'otwór nosowy';

ch. / s. nözdrva / nözdra;

ros. ноздри́;

ukr. ніздря;

*obličbje (n.)

1. 'wygląd zewnętrzny, kształt, postać',

2. 'oblicze, twarz'

Ogsłow.: stczes. oblićie 'oblicze, twarz'; pol. oblicze (od XIV w.) 'twarz';

'sylwetka duchowa, charakter', 'strona', stpol. (XIV-XV w.) także 'wygląd zewnętrzny, forma, kształt'; ros. обличье 'wygląd zewnętrzny'; 'twarz';

scs. обличие 'kszałt zewnętrzny'; 'obraz'.

Nazwa utworzona od wyrażenia przyimkowego *ob lice z przyrostkiem *-bje.

*oboči / *obočbje

Wyraz z przedrostkiem *ob- i podstawą *oko (Du. oči), przekształcany przez przyrostek *-bje (*obočbje); status prasłowiański formy bezsufiksalnej nie wydaje się obligatoryjny ${ }^{4}$ :

stczes. obočie (m.) 'brew'; 'powieka',

czes. oboči 'brew; brwi' (Kott, t. II, s. 233);

stsła. obočie 'brwi; powieka',

\footnotetext{
${ }^{3}$ Etymologia wg Boryś, op. cit., s. 367; Vas ES, t. III, s. 84-85.

${ }^{4}$ ESSJ, t. XXX, s. 126 wraz z literaturą.
} 
sła. obočie 'brwi' (SJSlow, t. II, s. 436);

dłuż. hobwoco 'brew', hobwocyje, hobwocyjo 'brwi' hobwoceji (Du.) 'ts.' (Muka, t. II, s. 388);

głuż. wo̊bwači ‘brwi: oczodół’ (Pfuhl, s. 1123);

srb.-csłow. обочие;

słń. obôčje 'oczodół, jama oczodołowa';

strus., rus.-csłow. обочие 'oczodół' (Srez M, t. II, s. 536; SRJ, t. XII, s. $130-131)$.

Por. *nadoči /*nadočbje.

*obry /*obrъve

Tak jak *bry, *brbve, jest to dawne pie. określenie brwi, podobnie jak *oko (pie. **ok - 'oko'); psł. *obry, *obrvbe < *obbry, *obbrbve, gdzie *ob- jest przyimkiem. Kompozitum *ob-bry $(\leq * * \underline{o b} \underline{\underline{h}} \underline{\underline{h}} \underline{\underline{h} \underline{u}-)}$ ) posiada kontynuanty w wielu językach słowiańskich:

czes. gwar. obrva (f.), zwykle w pl. obrvy; obrv (f.), pl. obrvy 'brew'; 'brwi'; obervě pl. 'brwi';

sła. obrv, pl. obrvy 'brew'; 'brwi', gwar. oberva pl. 'brwi';

pol. gwar. oberwie, obrwie 'brwi' (SGP, t. III, s. 371);

ch. / s. (rzadkie) obrv/ öbrva 'brew' gwar. öbrva, öbârva, oberva, обрв 'część biodra'(!); obrve 'brwi'; pl. öbarve 'ts.';

słń. obrvv 'brew', także 'dróżka, ścieżka' obrvva 'brew'; dawne obrv 'brew's.

*obustbje (n.) 'miejsce wokół ust'

W funkcji nazwy części twarzy prawdopodobna jest kalka z łac. peristoma, choć możliwe wydaje się dawne słowiańskie kompozitum *ob- 'wokół czego' + *usta, przekształcone przez *-ьje, por. brus. бу́сьнi, бусьня' 'usta' (*obustbni) oraz czes. obústní (przym.) 'okołoustny' (ESSJ, t. XXX, s. 243):

ch. / s. obušće 'okolice ust' (RJA, t. VIII, s. 489);

słń. obûstje 'okolice ust'; 'dolny bieg rzeki' (Plet, t. I, s. 754);

czes. obusti' zool. 'miejsce wokół otworu muszli skorupiaka'; bot. 'wypustki wokół otworu torebki nasiennej' (Kott, t. II, s. 252);

sła. obustie zool. 'okolice pyska u niższych gatunków zwierząt'; bot. 'wypustki wokół główki makówki';

stpol. obuście 'otwór ustny' (SStp, t. V, s. 389);

strus. обустие 'to, co otacza jakiś otwór' (SRJ, t. XII, s. 180).

*oko (Gen. sg *očese (Du. *oči, pl. *očesa) 'narząd wzroku, oko'

Jest to rzeczownik rodzaju nijakiego, w którym formant -es- rozszerza pierwotny wyraz pierwiastkowy; wtórne -es- występowało także w formach *ucho,

${ }^{5}$ Przykłady wg ESSJ, t. XXVI, s. 123-124. 
Gen. sg. *ušese (Du. uši). Formant ten nawiązuje do pie. -s- (Gen. sg. *očese $\leq$ $\left.* * o k^{u}-s\right)^{6}$. Psł. (ogsłow.) *oko wywodzi się od pie. rzeczownika odpierwiastkowego **ok $k^{u}$ - 'oko' (: pie. **ok - 'patrzeć'). Nazwa prasłowiańska spokrewniona jest z litewsk. akis 'oko', łotewsk. acs 'ts.', stang. éage (ang. eye), stwniem. ouga (współcz. niem. Auge), łac. oculus.

Słowiańskie nazwy oczu o zasięgu terytorialnym (regionalnym, gwarowym) są liczne, por. błg. зръколи, brus. глаза, балухі, зерки, ros. глаза, зенки, ukr. баки, глузги.

*ręsa, *ręsbna (f.) 'włosek na powiece, rzęsa'

Znaczenie etymologiczne to prawdopodobnie 'coś postrzępionego, jak włoski na powiece'; wyraz nie ma pewnej etymologii (wg Boryś, op. cit. s. 535); Max Vasmer (Vas ES, t. III, s. 476) sądził, iż możliwa jest również psł. postać *resa (por. ros. pесница.); Czernych IES, t. II, s. 113 wyprowadza *ręs $\leq$ *ręd-s(:*ręd b) z -s- sufiksalnym, podobnie jak *rus- $\leq * * r u d-s-$.

Ogsłow.: czes. řasa, r̆asnice 'rzęsa'; gwar. 'kłos owsa';

głuż. rjas, rjasnička;

pol. rzęsa 1. 'delikatne, krótkie włoski na brzegu powieki; 2. bot. 'Lemma, roślina wodna z rodziny rzęsowatych, o drobnych, płaskich pędach, unoszących się na powierzchni wody',

stpol. (XV w.) rzęsa czy rzasa bot. 'rzęsa drobna, Lemna minor',

pol. dial. też rzęsa 'kłos owsa';

błg. pecá 'frędzla'; ресни́u̧a 'rzęsa';

ch. / s. résa 'frędzla'; 'języczek (u górnego podniebienia)'; 'kwiatostan wierzby i brzozy; kotka'; bot. 'rzęsa, roślina wodna';

słń. rẹ́sa 'ość kłosa'; 'szorstki włos'; 'wąsy'; 'broda'; 'frędzla';

strus. рясьно, рясница 'rzęsa' (Srez M, t. III, s. 238); także ргосновы pl., ргоснове 'rzęsy' (Srez M, op. cit., s. 222);

ros. реснúua, częściej pl. реснúubl 'rzęsy' (Czernych op. cit. t. II, s. 112-113). W postaci ргосница występuje w słowniku z 1771 roku; рясни́ия rozpowszechnia się w języku ogólnym (literackim) od XVIII stulecia (Czernych, ib.);

brus. pэ́скіi 'rzęsy'7;

ukr. (w innym znaczeniu) рясни́ия, ряси́ия ‘fałda odzieży' (Hrin, t. IV, s. 93).

*tvarb (f.)

1. 'to, co zostało uformowane, utworzone'; 'żywa istota'; 'forma, kształt, postać',

2. (wtórnie) 'oblicze, twarz'

${ }^{6}$ Sławski ZS, t. II, s. 30.

${ }^{7}$ В. Ластоўскі, Падручны расійска-крыўскі (беларускі) слоўнік, Kowno 1924, s. 613, s. v. ресница. 
Rzeczownik rodzaju żeńskiego na $-\check{l}$-, utworzony za pomocą przyrostka $*_{-b}$ (ze wzdłużeniem samogłoski rdzennej $*_{o}>* a$ ) od psł. czasownika *tvoriti 'powodować powstanie czegoś, czynić, kształtować'.

Ogsłow.: czes. tvár 'oblicze, twarz'; 'istota, człowiek';

pol. twarz 'twarz, przednia część głowy ludzkiej'; dawniej 'stworzenie';

stpol. 'to, co zostało powołane do istnienia; stworzenie, człowiek, zwierzę'; 'kształt, postać'; 'osoba';

ros. mварь 'to, co jest stworzone; żywa istota', dial. 'gęba, twarz';

scs. mварь 'tworzenie'; 'to, co jest stworzone, stworzenie'.

Znaczenie 'oblicze, twarz' jest wtórne i pojawiło się w oparciu o znaczenie etymologiczne 'to, co jest ukształtowane: forma, kształt, postać' .

*usta

Psł. (ogsłow.) nazwa *usta spokrewniona jest ze stprusk. austo 'usta', litewsk. uostà, úostas 'ujście rzeki, zalew', łac. ōstium 'drzwi'; 'ujście, wejście, dostęp', awest. aošta 'warga'; pie. **ōuns-t- / ** zuss-t- (: **ōuss- 'usta') ${ }^{10}$.

*vědja (f.) 'rzęsa, 'powieka'

Psł. *védja nawiązuje do starszej formy tematu czasownika *věmb $(\leq * * v e \bar{e}-$ -mi), który przeszedł do bardziej produktywnej koniugacji *věděti, *vědati 'znać (jakąś rzecz, przedmiot)'; pie. **uoid - 'znać' < 'postrzegać wzrokiem, oczyma'. Rzeczownik * védja reprezentuje ten sam typ strukturalny, co *ědja 'to, co służy do jedzenia', ‘jedzenie; pokarm’ (: *ěmb, *ěsti). Podobnie zbudowany był rzeczownik *odedja, ze zmianą znaczenia 'to, co służy do okrycia, odzież, ubiór'.

Przyrostek ${ }^{*}$-ja kontynuuje pie. ${ }^{*}{ }^{*}-y \overline{a^{-1}}$ ' błg. веждa 'rzęsa'; ch. / s. вjëћa 'ts.'; scs. въжда 'powieka'; crus. въжда. Wahania znaczenia thumaczyć można realną bliskością oznaczanych części oka ${ }^{12}$.

W cerkiewnoruskim piśmiennictwie literackim XVI-XVII w. występują zapisy z substytucją graficzno-fonetyczną „є” wobec „, „” (Biblia Franciszka Skoryny: веже Nom. pl.), „и” wobec „њ” (Symeon Połocki: вижды Instr. pl.), „ж” wobec „жд” (zapis z XVI stulecia: въжи Dat. sg.) ${ }^{13}$; Berynda 26: въжда: въя, повъка.

*věja (f.) 'powieka'; 'rzęsa'

Uchwytny do określenia areał kontynuantów nazwy obejmuje języki białoruski, ukraiński, chorwacki, słoweński, czeski i słowacki:

8 SStp, t. 9, s. 233-234.

${ }^{9}$ Boryś, op. cit., s. 656; BrSE, s. 586; Vas, op. cit., t. IV, s. 32.

${ }^{10}$ Etymologia wg Boryś op. cit., s. 671 i Vas op.cit., t. IV, s. 172 wraz z literaturą.

11 Według Sławski ZS, t. I, s. 81 przyrostek *-ja tworzył głównie n. actionis, ulegające zwykle konkretyzacji w $\mathrm{n}$. acti, $\mathrm{n}$. instrumenti.

${ }_{12}$ Przykłady wg HSB, t. III, s. 65; SRJ, t. III, s. 51.

${ }^{13}$ ESBM, t. II, s. 81; ESUM, t. I, s. 408; ESJČ, s. 681; Vas ES, t. I, s. 285. 
brus. ве́йка, pl. ве́йкi 'rzęsy', stbrus. въя, вея 'powieka' (HSB, t. III, s. 171);

ukr. вí 'rzęsa',

Вій 'istota mityczna z powiekami do ziemi' (ESUM, t. I, s. 408), ukr. dial. вй́ко 'powieka' (ESUM, ib.), stukr. въя 'rzęsa' (ESUM ib. z XVII w.);

ch. / s. vjëda (książk.), ekawsk. vëđa, ikawsk. vije (Skok ER, t. III, s. 602);

słń. věja;

czes. vějička 'powieka';

sła. vejice pl. 'powieki'.

Psł. *věja wywodzi się od podstawy *věd-, przekształconej przez formant *-ja. Podstawa *věd- nawiązuje do archaicznego czasownika atematycznego *věmb $(\leq * * v e \bar{d}-m i)$. Taką etymologię przyjmuje BrSE, s. 615-616, ESUM, t. I, s. 408; Skok ER, t. III, s. 602.

*věka (f.), *věko (n.)

'przykrycie, pokrycie, wieko, pokrywa', 'powieka'

Drugie z wymienionych znaczeń ilustrują:

czes. (oční) víčko (też klapka: Kott, t. IV, s. 648; SJČ, t. IV, s. 81);

sła. viečko;

strus. въько (SRJ, t. III, s. 54-55),

stbrus. въљо (HSB, t. III, s. 71),

ros. ве́ко, pl. ве́ки (Czernych IES, ib., t. I, s. 139); dial. pn. ве́ко 'rzęsa' (SRNG, t. IV, s. 101),

ukr. вiко;

słń. véka;

scs. въко.

Pnsłow. *pověka (f.). 'powieka':

Wyraz występuje w brus. паве́ка, ukr. повіка, dial. павіко (n.); pol. pоwieka. Funkcja przedrostka * po- nie jest jasna (Boryś, op. cit., s. 473). Jest to zapewne pierwotny rzeczownik z przyrostkiem *-ka, utworzony od *vě- $(* * v \bar{e}-)$, który ma bałtyjskie odpowiedniki $\mathrm{z} * * v \overline{-}$ - por. litewsk. vókas 'powieka', vóka 'pokrywa', łotewsk. vâks 'pokrywa'. Dla *povéka można więc przyjąć znaczenie etymologiczne 'to, co przykrywa, pokrywa'. Na części Słowiańszczyzny nazwa występuje zamiast *védja (Br, op. cit., s. 615-616; Czernych, op. cit., t. I, s. 139).

Znaczenie 'powieka' oddają również błg. клеnáч, ch. / s. ойнй ка̄naк ( $\leq$ tur. kapak 'pokrywa'), maced. каnaк ${ }^{14}$.

psł. dial. *vrga (f.)

${ }^{14}$ Przykłady wg Czernych, op. cit., t. I, s. 139. 
'każdy z dwóch fałdów skórnych ograniczających od przodu otwór ustny'

W takim znaczeniu wyłącznie polskie, skąd zapewne czes. dial. laskie varga 'pysk konia, krowy', także sła. dial. varga 'warga', ukr. dawne (XVII w.) oraz dial. вápza 'ts.', pl. вápzu 'podbródek, broda', во́рга 'warga'.

Według Wiesława Borysia ${ }^{15}$ wyraz prawdopodobnie tożsamy jest z pdsłow. błg. dial. връга (въ́рга, во̂рга) 'narośl na ciele zwierzęcia lub na roślinie', 'guz od uderzenia', 'opuchlizna', 'sęk w drzewie', 'małe wzniesienie', maced. врга 'narośl na ciele, na drzewie', maced. dial. въ́pza 'guz', ch. / s. vìga 'guz od uderzenia'.

Psł. dial. *vrga 'nabrzmienie, wypukłość'; może od pie. **uerg ${ }^{h}$-, będącego rozszerzeniem pierwiastka **uer- 'kręcić, wyginać'.

*zenica (f.) 'źrenica'

Według Maxa Vasmera (Vas ES, op. cit., t. II, s. 94) nazwa ta nie posiada pewnej etymologii. Nowsze rozwiązanie podaje Wiesław Boryś (Boryś, op. cit., s. 749), iż jest to prawdopodobnie przekształcenie psł. *zěnica, zdrobnienia od hipotetycznego *zèna 'źrenica', derywatu od *zějg, *zbjati 'otwierać się, rozwierać się, stać otworem' z sufiksem *-na.

Ogsłow.: ch. / s. зјёнииа;

słń. zrenica 'źrenica';

ros. зенйиа; dial. зе́ньки, pl. зе́ны 'осzу'; 'źrenice';

strus. зънииа;

brus. dial. зе́на 'źrenica', зе́нка 'ts.'; зіньки 'źrenice';

ukr. dial. зіньки 'ts.';

czes. zenice;

sła. zrenica;

pol. źrenica; stpol. także źrzenica, dial. żrenica, zrenica, źrynia, zdrzenica, dr-zenica.

Wtórna polska źrenica i jej odpowiedniki w niektórych językach słowiańskich pojawiła się w rezultacie skojarzenia nazwy z psł. *zbrěti 'patrzeć'. W gwarach okolic Łowicza notowane są synonimiczne panienka, patrzączka.

\section{WNIOSKI I UWAGI KOŃCOWE}

Artykuł ten przybliża dotychczasową wiedzę czytelnikowi, zebraną ze słowników etymologicznych, artykułów i monografii oraz proponuje własną etymologię dla nazw *vědja 'rzęsa', 'powieka', *věka (f.), *věko (n.) 'powieka', pnsłow. *poveka 'ts'.

Rozróżnienie „ręka prawa' „aktywna” / „ręka lewa” „pasywna” motywowane fizjologicznie mogło przenosić się na inne, z natury parzyste, organy

\footnotetext{
${ }^{15}$ Boryś, op. cit., s. 678.
} 
ludzkiego ciała, tj. na kolana, nogi, oczy, uszy. Organy te, w zależności od pozycji „prawa (strona)" / „lewa (strona)” były pozytywne (męskie) lub negatywne (żeńskie) ${ }^{16}$.

W tradycji kulturowej Słowian wschodnich i Słowian południowych prawemu oku przypisany jest atrybut „szczęśliwe”, lewemu - „nieszczęśliwe” (Иванов, Топоров 1974: 268). W tradycji polskiej drugą z wymienionych właściwości przypisuje się oczom, nogom i rękom, por. fraz. spojrzeć krzywym (lewym, kosym) okiem, wstać lewa noga, dać coś lewa ręka.

Jednym z najstarszych i najpowszechniejszych wierzeń u Słowian jest przekonanie, że ludzkie oko ma moc rzucania uroku czy klątwy. Już sam fakt, że przygląda się nam osoba podejrzewana o uprawianie czarów stwarza potencjalną groźbę klątwy, lęk przed „złym okiem” funkcjonuje również współcześnie. $\mathrm{W}$ dawnych czasach wierzono, że istnieje promień rzucany przez oko. Z ludzkiej źrenicy emanować miała potężna siła, uważano, że niedobry człowiek potrafi manipulować i wzmacniać swoje promienie, by siać zniszczenie i zło. "Złe oko" zwykle kojarzono ze starszymi kobietami, które uważano za czarownice, zwłaszcza, jeśli miały oczy różnej barwy.

Przed „złym okiem” chroniły amulety i talizmany; w mitach greckich ochronę dawała tarcza Ateny z głową Meduzy, tarcze, które broniły nie tylko przed strzałami i włóczniami, lecz również przed „złym” wzrokiem wroga (Gordon 1994).

Przed ,złym okiem” w folklorze Słowian ochrania jarzębina, jałowiec, żelazo i podkowa, a także znaki czynione dłonią (por. figa z makiem), wypowiedzenie stosownego zaklęcia, odczynienie uroku. Podobnie żegnanie się znakiem krzyża stanowi jeszcze jedną formę manualnej ochrony przed ,złym okiem”.

Mózg ludzki dostrzega najpierw podstawowy kształt twarzy, następnie ustala położenie względem siebie oczu, nosa, itd. Dopiero na końcu „spogląda” na twarz całościowo.

Nauka współczesna ustaliła, iż niczego innego nie rozpoznajemy tak szybko jak twarzy człowieka i pamiętamy o wiele dłużej niż imię, nazwisko oraz adres. Odpowiada za to specjalny obszar mózgu, tzw. zakręt wrzecionowaty (gyrus fusifomis). Mózg analizuje twarz jako całość i w tym celu musi wpierw zdecydować, czy to, co widzą nasze oczy, w ogóle nią jest. Następnie zaczyna właściwe rozpoznawanie, równolegle „skanując” emocje wypisane na obliczu: gdy widzimy twarz, nie tylko ustalamy tożsamość, lecz również oceniamy stan psychiczny danej osoby i przygotowujemy odpowiednią reakcję. Tradycyjnie i potocznie przyjmuje się, że powyższą funkcję pełnią ludzkie oczy.

${ }^{16}$ Nie były zróżnicowane w tym względzie fizjologicznie „nieruchome” organy, tj. brwi, kolana, uszy. 


\section{WYKAZ SKRÓTÓW}

\section{Słowniki}

Berynda

Boryś SE

$\mathrm{Br} \mathrm{Se}$

Czernych IES

ESBM

ESJČ

ESSJ

ESUM

Geb S1

Hrin

HSB

Kott

Machek ESJČ

Muka

Pfuhl

Plet

SGP

Skok ER

S SlovJ

Sławski ZS

Srez M

SRJ

SRNG

SStp

Vas ES
- П. Берында (1961), Лексикон славенороськый (1627), opr. W. W. Nimczuk, Kijów.

- W. Boryś (2005), Stownik etymologiczny języka polskiego, Kraków.

- A. Brückner (1957), Stownik etymologiczny języka polskiego, Warszawa.

- П. Я. Черных, Историко-этимологический словарь русского языка, Moskwa.

- Этыммалагичны слоўнік беларускай мовы (1978 і n.), red. W. W. Martynow, Mińsk.

- J. Holub, F. Kopečný (1952), Etymologický slovnik jazyka českého, Praga.

- Этимологический словарь славянских языков. Праславянский лексический фонд (1974 i n.), t. 1-31, red. O. N. Trubaczow, Moskwa.

- Этимологічный словник украӥнської мови (1982 і n.), red. nacz. O. S. Melnyczuk, Kijów.

- J. Gebauer (1970), Slovnik staročeský, t. I-II, Praga (I wyd. 1903-1916).

- Б. Грінченко (1907-1909), Словарь української мови, t. I-IV, Kijów.

- Гістарычны слоўнік беларускай мовы (1982 і n.), red. nacz. A. I. Żurawski, Mińsk.

- F. Š. Kott (1878-1893), Česko-německý slovnik, t. I-VII, Praga.

- V. Machek (1968), Etymologický slovník jazyka českého, Praga.

- E. Muka (1911-1928), Stownik dolnoserbskeje rečy a jeje narečov, t. I-III, Petrograd-Praga.

- Dr. Pfuhl (1866), Eužiski-serbski słownik, Budziszyn.

- M. Pleteršnik (1894-1895), Slovensko-nemški slovar, t. I-II, Lublana.

- J. Karłowicz (1900-1911), Stownik gwar polskich, t. I-VI, Kraków.

- P. Skok (1971-1974), Etimologijski rječnik hrvatskoga ili srbskoga jezika, t. I-IV, Zagrzeb.

- Slovník slovenského jazyka (1959-1965), red. Š. Peciar, t. I-IV, Bratysława.

- F. Sławski, Zarys słowotwórstwa prastowiańskiego, [w:] Stownik prasłowiański (1974-1979), t. I-III, Wrocław.

- И. И. Срезневский (1893-1912), Материалы для Словаря древнерусского языка по письменным памятникам, t. I-III, St.-Petersburg.

- Словарь русского языка XI-XVII вв. (1975 і n.), red. S. G. Barchudarow (t. I-VI), F. P. Filin (t. VII-IX), Moskwa.

- Словарь русских народных говоров (1965 i n.), red nacz. F. P. Filin, Moskwa-Leningrad.

- Stownik staropolski (1953 i n.), red. S. Urbańczyk, Warszawa.

- М. Фасмер (1964-1973), Этимологический словарь русского языка, tłum. z niemieckiego i uzupełnienia O. N. Trubaczowa, t. I-IV, Moskwa.

\section{Języki i dialekty}

$\begin{array}{llll}\text { ang. } & - \text { angielski } & \text { ogsłow. } & \text { - ogólnosłowiański } \\ \text { awest. } & - \text { awestyjski } & \text { pdsłow. } & \text { - południowosłowiański } \\ \text { błg. } & - \text { bułgarski } & \text { pie. } & - \text { praindoeuropejski } \\ \text { brus. } & - \text { białoruski } & \text { pnsłow. } & - \text { północnosłowiański }\end{array}$




\begin{tabular}{|c|c|c|c|}
\hline ch. / s. & - serbski i chorwacki & psł. & - prasłowiański \\
\hline crus. & - cerkiewnosłowiański & ros. & - rosyjski \\
\hline czes. & - czeski & rus.-csłow. & - rusko-cerkiewnosłowiański \\
\hline dłuż. & - dolnołużycki & scs. & - staro-cerkiewno-słowiański \\
\hline ekawsk. & - ekawski & sła. & - słowacki \\
\hline głuż. & - górnołużycki & srb. & - serbski \\
\hline ikawsk. & - ikawski & srb.-csłow & - serbsko-cerkiewnosłowiański \\
\hline litewsk. & - litewski & st. & $\begin{array}{l}\text { - staro- (przed oznaczeniem } \\
\quad \text { języka, np. strus - staroruski) }\end{array}$ \\
\hline łac. & - łaciński & stprus. & - staropruski \\
\hline maced. & - macedoński & stwniem. & - staro-wysoko-niemiecki \\
\hline niem. & - niemiecki & tur. & - turecki \\
\hline pol. & - polski & wschsłow. & - wschodniosłowiański \\
\hline
\end{tabular}

\section{Inne skróty}

$\begin{array}{llll}\text { Acc. } & - \text { Accusativus } & \text { fraz. } & \text { - frazeologizm } \\ \text { bot. } & \text { - botaniczny } & \text { m. } & \text { - masculinum } \\ \text { Dat. } & - \text { Dativus } & \mathrm{n} . & - \text { neutrum } \\ \text { dial. } & - \text { dialektyczny } & \text { pl. } & - \text { pluralis } \\ \text { Du. } & - \text { Dualis } & \text { pn. } & - \text { północny } \\ \text { Gen. } & - \text { Genetivus } & \text { sg. } & - \text { singularis } \\ \text { gwar. } & - \text { gwarowy } & \text { zool. } & - \text { zool. } \\ \text { f. } & - \text { femininum } & & \end{array}$

\section{Bibliografia}

Gordon S. (1996), Księga klątw, 1994, thum. T. Oljasz, M. Łakomski, Warszawa.

Siatkowski J. (2010), Stowiańskie nazwy 'twarzy' $i$ 'policzka' $w$ świetle materiatów gwarowych i źródet historycznych, ,Rocznik Slawistyczny”, t. LIX, Warszawa, s. 91-120.

Иванов В. В., Топоров В. Н. (1974), Исследования в области славянских древностей, Москва.

\section{Grażyna Rytter}

\section{THE NAMES OF THE PARTS OF FACE IN SLAVONIC LANGUAGES}

(Summary)

Etymological sketch presents 19 words, in the majority of all-Slavonic range. They are thematically connected with Slavic *tvarb. The article also contains comments about Slavs' cultural 
tradition, which ascribes attribute "lucky" to the right eye and "ill-fated" to the left one. To the oldest and most popular beliefs preserved in the Slavonic folklore belongs conviction that human eye has a power of casting a spell or a curse on somebody.

Keywords: parts of face, Slavonic languages, Slavonic folklore, etymology.

\section{NAZWY CZĘŚCI TWARZY W JĘZYKACH SLOWIAŃSKICH \\ (Streszczenie)}

Szkic etymologiczny prezentuje 19 wyrazów, w większości o zasięgu ogólnosłowiańskim. Są one tematycznie związane z psł. *tvarb. Artykuł zawiera również uwagi o tradycji kulturowej Słowian, która prawemu oku przypisuje atrybut „,szczęśliwe”, lewemu - „nieszczęśliwe”. Do najstarszych i najpowszechniejszych wierzeń zachowanych w folklorze słowiańskim należy przekonanie, że ludzkie oko ma moc rzucania uroku czy klątwy.

Słowa kluczowe: części twarzy, języki słowiańskie, folklor słowiański, etymologia. 